\title{
Tekirdağ ilinde yetişen zeytin ağaçlarında dal kanseri hastalığı etmeni Pseudomonas savastanoi pv. savastanoi'nin tanısı ve antagonist bakteriyel izolatlar ile biyolojik mücadelesi
}

Identification of bacterial knot disease agent Pseudomonas savastanoi pv. savastanoi in Tekirdag province and their biological control by using antagonistic bacterial isolates

\author{
Ece BiTGEN ${ }^{1}$, Mustafa MiRik ${ }^{2}$ (iD \\ ${ }^{1}$ Süleymanpaşa Ziraat Odası, 100. Yıl Mah. Şenkal Sk. No:1, 59100, Tekirdağ. \\ ${ }^{2}$ Tekirdağ Namık Kemal Üniversitesi, Ziraat Fakültesi, Bitki Koruma Bölümü, Tekirdağ.
}

MAKALE BILGISI / ARTICLE INFO

\section{Makale tarihçesi / Article history:}

DOI: $10.37908 /$ mkutbd.881977

Geliş tarihi /Received:17.02.2021

Kabul tarihi/Accepted:27.04.2021

\section{Keywords:}

Olive knot disease, olive, LOPAT, identification, biocontrol.

Corresponding author: Mustafa MiRik

$\triangle:$ mmirik@nku.edu.tr

\section{ÖZET / A BSTRACT}

Aims: Olive knot disease on olives (Olea europaea) trees is caused by the bacterium Pseudomonas savastanoi pv. savastanoi . Causal disease agent typical causes knot (known as tumor or galls) on branches of infected olive trees. This study was conducted to investigate the identification, prevalence and biological control possibilities of Pseudomonas savastanoi pv. savastanoi in several orchards in provinces of Tekirdag in Trakya region during 2016-2017 growing seasons.

Methods and Results: Total of 78 infected knot samples collected from several olive cultivars growing in province and 52 bacterial isolates were obtained and identified. All of the isolates were gram negative and were found to be in the LOPAT $1 \mathrm{~b}$ group with oxidase, pectolytic activity, levan and arginine dihydrolase negative, caused hypersensitive reactions in tobacco leaves. According to results of biochemical and morphological studies, all isolates were identified as $P$. savastanoi pv. savastanoi. According to survey results, the prevalence of olive knot disease is $86.6 \%$ in Tekirdağ province. Total of 110 putative antagonist bacterial isolates were obtained from healthy olive trees and soils where they grow. As a result of dual culture test with pathogen in vitro conditions, among the 110 putative antagonist bacterial isolates, 23 antagonist bacterial isolates suppressed bacterial growth on nutrient media by producing an inhibition zone index values of 3.5-28.00.

Conclusions: This study revealed that knot disease on olives is an important disease and it should be considered for disease management in the Tekirdağ province.

Significance and Impact of the Study: This study clearly revealed the current status of olive knot diseases in olive growing areas in Tekirdağ province. Revealing the current situation of the disease and their possible biological control by antagonist bacterial agents is also important for the other studies aiming at disease management.

\footnotetext{
Atıf / Citation: Bitgen E, Mirik M (2021) Tekirdağ ilinde yetişen zeytin ağaçlarında dal kanseri hastalığı etmeni Pseudomonas savastanoi pv. savastanoi'nin tanısı ve antagonist bakteriyel izolatlar ile biyolojik mücadelesi. MKU. Tar. Bil. Derg. 26(2) : 326-336. DOI: 10.37908/mkutbd.881977
} 
işlenebilen tarımsal bir ürün olmasının yanı sıra, zeytinyağına ve salamuraya işlenmesi nedeniyle de tarıma dayalı sanayi ve ihracatta vazgeçilmez ürünler arasında yer almaktadır. Zeytin, dünya üzerinde Türkiye'nin de içinde bulunduğu orta kuşakta ve Akdeniz ikliminin etkili olduğu yerlerde doğal olarak yetişir (Gemas ve ark., 2004).

Dünya zeytin üretim alanları yaklaşık 10 milyon hektar düzeyindedir. 2019 yılı verilerine göre Dünya zeytin üretimi 19.464 .495 ton olarak açıklanmıştır. İspanya 5.965 .080 ton ile zeytin üretiminde 1 . sırada yer alırken bu ülkeyi Italya 2.194.110 ton, Fas 1.912.238 ton, Türkiye 1.525.000 ton zeytin üretimi ile takip etmektedir (FAO, 2019). Türkiye zeytin üretimi özellikle Ege ve Akdeniz bölgesinde bulunan illerde yoğunlaşmıştır. Türkiye genelinde zeytin yetiştiriciliğinin yapıldığı en önemli iller Aydın, Manisa, Muğla, İzmir, Balıkesir ve Hatay'dır.

Türkiye' de çok geniş alanlarda üretimi yapılan, iç tüketim ve ihracatımız için önemli bir yere sahip olan zeytin ağaçlarında ekonomik kayıplara neden olan birçok hastalık ve zararlı bulunmaktadır. Bu etmenlerden dolayı gerek zeytinyağı ve gerekse sofralık zeytin üretim miktarının azalmasına neden olmaktadır. Zeytin ağaçlarında fungal hastalıklardan Verticillium solgunluğu (Verticillium dahliae Kleb.), zeytin halkalı leke hastalığı (Spilocaea oleaginae (Cast) Hughes (=Cycloconium oleaginum Cast) ile bakteriyel hastalıklardan Pseudomonas savastanoi pv. savastanoi (P.s. pv. savastanoi) (Smith, 1908) Janse (1982)'nin neden olduğu zeytin uru veya zeytin dal kanseri hastalığı epidemi yaptığı yıllarda üründe ciddi verim ve kalite kayıplarına neden olmaktadır. Bakteriyel hastalık etmeni $P$. s. pv. savastanoi dünya genelinde zeytin yetiştirilen hemen hemen her ülkede görülmektedir (Janse, 2006).

Ülkemizde bu hastalığın, zeytinlerde varlığı uzun zamandır bilinmesine rağmen ilk çalışmalar Ege bölgesinde Azeri (1993), Aydın ve Muğla illerinde Tatlı ve Benlioğlu (2004), Batı Akdeniz Bölgesinde Basım ve Ersoy (2000), Doğu Akdeniz Bölgesinde (Mirik ve ark., 2004), Marmara Bölgesinde (Mirik ve ark., 2007) yapılan sörvey çalışmaları ile ortaya konulmuştur. Zeytin dal kanseri hastalığının etmeni Oleceae ve Apocynaceae familyasına ait farklı bitkilerde yaprak, sürgün ve gövdede urlara oluşumuna neden olur. Yapılan hastalık sörveyleri ve tanılama çalışmalarında, başta zeytin (Olea europea L.) (Smith, 1908; Young ve ark., 1978) olmak üzere, Zakkum (Nerium oleander L.) (Wilson, 1965), Yasemin (Jasminium officinale L.) (Janse, 1981), Dişbudak (Fraxinus excelsior L.) (Janse, 1981) ve Forzitya çalısı (Forsythia sp.) (lacobellis ve ark., 1998), Mersin çalısı (Mirik ve ark., 2006), Cılbırtı çalısı (Fontanesia phillyreoides) (Mirik ve ark., 2011), Çin ardıcı
(Loropetalum chinense) (Conner ve ark., 2013) ve nar ağaçları (Bozkurt ve ark., 2014) hastalık etmenin konukçuları olarak bildirilmiştir.

Bakteriyel hastalıklara karşı genelde bakırlı kimyasal ilaçlar kullanılmakta olup, hastalıkla mücadelede dayanıklı çeşitlerin kullanımı ile kültürel yöntemlerde önemlidir (Ramos ve ark., 2012). Bakteriyel hastalıklarla mücadelede kullanılan bakırlı preparatlar sistemik olmayan enfeksiyonlarda başarı gösterirken bitkinin iletim demetlerinde veya iç kısmında bulunan bakterileri engellemede yeterli olamamaktadır. Bu nedenle son yıllarda başta $P$. savastanoi pv. savastanoi olmak üzere ur oluşturan bakteriyel hastalıklarla mücadelede kimyasallara alternatif olarak antagonist veya bitki gelişimini teşvik eden bakteri izolatlarının kullanıldığı biyolojik mücadele, çeşitli bitki ekstratları ve uçucu yağların kullanımı gibi alternatif yöntemlere yönelik çalışmalar yapılmaktadır (Krid ve ark., 2011; Oksel ve Mirik 2015; Soylu ve ark., 2016; Mina ve ark., 2017; Bozkurt ve Soylu, 2019; Bozkurt ve ark., 2020).

Bu çalışma ülkemiz zeytinciliğinde yeri olan Tekirdağ ilindeki zeytin bahçelerinde dal kanseri hastalığı etmeni $P$. s. pv. savastanoi açısından incelemek, etmeni tanılamak, hastalığın Tekirdağ ilinde zeytin bahçelerindeki yaygınlık oranını saptamak, etmene karşı in vitro koşullarda bakteriyel antagonistler ile biyolojik mücadele olanaklarını ortaya koymak amacıyla ele alınmıştır.

\section{MATERYAL ve METOD}

\section{Hastalıklı ve sağlıklı bitki örneklerinin toplanması}

Sörvey çalışmalarında, inceleme yapılan bahçelerde hastalık etmeninin yaygınlığı Lazarow (1961) metoduna göre belirlenmiştir. Sörvey çalışmaları, 2016 ve 2017 yıllarında zeytin yetiştiriciliğinin yoğun yapıldığı Şarköy ilçesi ile Mürefte, Güzelköy, Hoşköy köylerinde (mahallelerinde) bulunan zeytin bahçelerinde yapılmıştır. Her incelemede, bahçede bulunan ağaçlar zeytin dal kanseri etmeni $P$. s. pv. savastanoi belirtileri açısından görsel olarak incelenmiş ve tipik zeytin dal kanseri belirtisi olan, ur oluşumu gösteren dallardan örnekler alınarak laboratuvara getirilmiştir. Ayrıca hastalık etmenine karşı biyolojik mücadele kapsamında kullanılacak aday antagonist bakterilerin izolasyonu için hastalıklı bitki örneklerinin toplanıldığı zeytin bahçelerinden, hastalık belirtisi göstermeyen zeytin ağaçlarından çiçek, dal ve sürgün uç yaprakları ayrıca toprak örnekleri toplanmıştır. Laboratuvara getirilen örneklerden 24-48 saat içerisinde bakteriyel etmen ve antagonist bakteri izolasyonları yapılmıştır. Çalışma kapsamında, 2016 üretim yılında 11 ve 2017 üretim 
yılında 4 zeytin bahçesi olmak üzere toplam 15 zeytin bahçesi incelenmiştir.

Pseudomonas savastanoi pv. savastanoi izolatların izolasyonu

Laboratuvara getirilen ve zeytin dal kanseri etmeni $P$. $s$. pv. savastanoi ile enfekteli olduğu düşünülen örneklerin urlu kısımlarından küçük parçalar alınmış, bu parçalar $\% 2$ 'lik sodyum hipoklorit çözeltisinde 2 dakika ve daha sonra 3 kez steril saf su içerisinde 2 şer dakika bekletilerek yüzey dezenfeksiyonu yapılmış, daha sonra steril kurutma kağıtları ile kurulanmıştır. Yüzey dezenfeksiyonu yapılan bu parçalar saline buffer ile steril havanlarda ezildikten sonra örnekler 20-30 dk steril kabinde bekletilmiştir. King $B$ besi ortamı içeren petrilere bakteri süspansiyonundan bir öze dolusu alınarak üç çizgi yöntemiyle ekim yapılmıştır (Janse, 2006). Mirik ve ark. (2008) belirttiği gibi petri yüzeyinde sarı renkli saprofit bakteri gelişimini engellemek amacıyla Petriler 48 saat $25{ }^{\circ} \mathrm{C}$ ' de inkübe edildikten sonra $+4{ }^{\circ} \mathrm{C}$ ' de 24 saat süresince buzdolabında bekletilmiştir. Bu aşamadan sonra King $B$ besi yerinde zayıf floresan tipte, küçük yuvarlak ve kabarık olmayan tipte gelişen koloniler saflaştırılmıştır. Saflaştırılan koloniler, $24{ }^{\circ} \mathrm{C}$ 'de 24- 48 saat süre ile inkübatörde gelişim gösterdikten sonra, içerisinde Yeast Dekstrose Chalk Agar (YDCA) besi ortamı bulunan tüplere aktarılmıştır. Krem renkli floresan koloni gelişimleri gösteren izolatlar seçilerek aşağıda detaylı bir şekilde açıklanan tütün bitkisinin genç yapraklarında aşırı duyarlılık (HR, hypersensitive testi), biyokimyasal ve LOPAT testleri için kullanılmıştır (Lelliot ve Stead,1987).

\section{Pseudomonas savastanoi pv. savastanoi izolatların tanılanması}

King $\mathrm{B}$ besi yerinde gelişen kolonilerden saflaştırılan Bakteriyel izolatların biyokimyasal ve morfolojik tanılanması amacıyla aşağıda belirtilen biyokimyasal ve morfolojik testlemeler yapılmıştır.

\section{Gram reaksiyon testi}

Testleri Taze hazırlanan $\% 3^{\prime}$ lük potasyum hidroksit solüsyonundan lam üzerine bir damla damlatılıktan sonra $P$. S. pv. savastanoi izolatlarının 24 saatlik kültürlerinden steril kürdanla alınarak solüsyona karıştırılmıştır. Bunu takip eden 20-30 saniye içerisinde kürdan yukarı kaldırıldığında viskoz, yapışkanımsı sünmenin oluşması gram negatif olarak değerlendirilmiştir. Gram reaksiyon testinde kontrol olarak Prof. Dr. Yeşim AYSAN' dan alınan gram pozitif özelliğe sahip $\mathrm{Cmm}$ 3a-r kodlu Clavibacter michiganensis subsp. michiganensis kültürü kullanılmıştır.

\section{Levan oluşumu}

Levan oluşumunu gözlemek için besi ortamı olarak \%5 oranında sakkoroz içeren NA kullanılmıştır. NA besi ortamına üç çizgi yöntemi ile ekim yapılmıştır. 3-5 günlük inkubasyondan sonra pozitif reaksiyon verenler beyaz mukoid, tümsek şeklinde koloni oluşumuna göre değerlendirilmiştir. Levan oluşumunda pozitif kontrol olarak Erwinia amylovora 57 izolatı kullanılmıştır.

\section{Oksidaz testi}

Oksidaz testi için, \%1'lik taze olarak $\mathrm{N} ; \mathrm{N} ; \mathrm{N} ; \mathrm{N}$; Tetramethyl-p-phenylendiamine dhydrochloride solüsyonu hazırlanmış ve steril filtre kağıdına damlatılmıştır. P. s. pv. savastanoi izolatları ve referans izolatın 24 saatlik kültüründen steril kürdanla alınarak ıslak kurutma kağıdına yayıımıştır. Yayılmadan 10 saniye sonra maviye dönerse pozitif, 15 - 60 saniye sonra maviye dönüşürse geç pozitif, 60 saniye sonrası mavi renk oluşumu gözlenmez ise negatif olarak değerlendirilmiştir (Kovacs, 1956).

\section{Pektolitik aktivite testi}

Patates yumrularının yüzeysel dezenfeksiyonunu sağlamak için önce yıkanmış ve daha sonra \%1 $\mathrm{NaOCl}^{\prime}$ da 3 dakika bekletilmiştir. Yumruların $\mathrm{NaOCl}^{\prime}$ den arındırılması için $3 \mathrm{kez}$ steril saf su ile durulanmıştır. Her bir petriye, petri çapına göre steril kurutma kağıtları kesilerek yerleştirilmiş ve steril damıtık su ile nemlendirilmiştir. Patates yumruları soyulduktan sonra 7-8 mm kalınlığında dilimlenip petrilere yerleştirilmiştir. Her bir patates dilimi üzerinde bakteri kültürleri öze ile sürülmüştür. 24 saatlik inkübasyondan sonra inokulasyon noktasında yumuşama varsa pozitif sonuç olarak değerlendirilmiştir.

\section{Arginin dihydrolase testi}

Arginin dihiydrolase testi için $1.0 \mathrm{~g}$ Peptone, $5.0 \mathrm{~g} \mathrm{NaCl}$, $0.3 \mathrm{~g} \mathrm{~K}_{2} \mathrm{HPO}_{4}, 0.01 \mathrm{~g}$ Phenolred, $10 \mathrm{~g} \mathrm{~L}(+)$ Arginin HCL, 3 g Agar $1000 \mathrm{ml}$ saf su içerisinde ısıtılarak hazırlanan besi ortamı $45^{\circ} \mathrm{C}^{\prime}$ ye kadar soğutulduktan sonra $\mathrm{pH}: 7.2$ olacak şekilde ayarlanmıştır. $3 \mathrm{ml}$ lik tüplere konulduktan sonra $121{ }^{\circ} \mathrm{C} \quad 15$ dakika otoklavda sterilizasyon sağlanmıştır. $P$. s. pv. savastanoi izolatları ve referans izolatın 24 saatlik kültüründen yarma aşılama yapılmıştır. Üzeri $2 \mathrm{ml}$ steril vaspar ile örtülmüştür. Kontrol olarak 3 tüp aşılanmamıştır 10-12 günlük bir inkübasyondan sonra kırmızı renkteki besi ortamı vişne rengini veren kültürler pozitif olarak değerlendirilmiştir (Lelliott ve Stead, 1987).

Tütün yapraklarında aşırı duyarlılık testi (HR, hypersensitif reaksiyon) 
Tütün 3-4 yapraklı duruma geldiğinde $10^{8} \mathrm{hücre} / \mathrm{ml}$ lik bakteri süspansiyonunun ince uçlu enjektör kullanılarak yaprağın alt yüzeyinden iki damar arasına hücreler arasındaki alana enjekte edilmiştir. İnokule edilen kısımların 24-48 saat sonra nekroz şeklinde belirti vermesi pozitif olarak değerlendirilmiştir (Klement ve Goodman, 1967).

LOPAT testinde ve tütün bitkisinde (Nicotiana tabacum) hipersensitif reaksiyon (HR) pozitif sonucunu veren izolatlar eğik olarak hazırlanmış YDCA besi ortamına ekim yapılarak daha sonraki çalışmalarda kullanılmak üzere +4 ${ }^{\circ} C^{\prime}$ deki buzdolabında muhafaza edilmiştir.

\section{Hastalık etmenin patojenisite testi}

Patojenisite testi etmenin tanısında kullanılan önemli bir yöntemdir. İzolasyonu yapılan NA besi ortamında geliştirilen 24 saatlik $P$. s. pv. savastanoi izolatları zeytin fidanlarında yaralar oluşturularak inokule edilmiştir. Inokule edilen bölgeler nemlendirilmiştir. Yaklaşık 60 gün sonra fidanlar değerlendirmeye alınmıştır. Yara dokusu etrafına açık yeşil renkte ur belirtisi izolatın potansiyel hastalık etmeni olduğunu göstermiştir. Negatif kontrolde steril saf su kullanılmıştır (Janse, 1981)

\section{Aday antagonist bakteri izolatların izolasyonu}

Hastalığın gözlendiği bahçelerdeki sağlıklı Zeytin ağaçlarının dal, çiçek ve sürgün ucu yaprakları ile topraklardan aday antagonist ve bitki gelişimini teşvik eden aday bakteri izolatlarının izolasyonlarını yapmak için, toplanan örneklerden 10'ar g tartılarak, $90 \mathrm{ml}$ steril Nutrient Broth (NB) içerisine konulmuş ve orbital çalkalayıcı üzerinde $60 \mathrm{dk}$ karıştırılmaya bırakılmıştır. Daha sonra süspansiyondan $1 \mathrm{ml}$ alınarak içerisinde $9 \mathrm{ml}$ steril salin buffer bulunan tüplere aktarılarak sulandırma serileri hazırlanmıştır. Seyreltme serilerinde $100 \mu \mathrm{l}$ alınarak içerisinde NA besi ortamı bulunan petrilere yayma yöntemi ile ekim yapılmıştı. Ekimi yapılan petriler $25{ }^{\circ} \mathrm{C}$ ' de inkübatörde inkubasyona bırakılmıştır. İnkübasyon sonunda morfolojik olarak farklı kolonilerden rastgele aday bakteri izolatları seçilmiş ve saflaştırılmaları yapılmıştır.

Sağlıklı zeytin ağaçlarının yetiştiği topraktan alınan örneklerden 10'ar g tartılarak, üzerlerine $90 \mathrm{ml}$ steril NB eklenerek süspansiyonları ilave edilmiş, daha sonra tüpler orbital çalkalayıcı üzerinde $60 \mathrm{dk}$ karıştırılmaya bırakılmıştır. Daha sonra süspansiyondan $1 \mathrm{ml}$ alınarak içerisinde $9 \mathrm{ml}$ steril salin buffer bulunan tüplere aktarılarak sulandırma serileri hazırlanmıştır. Seyreltme serilerinde $100 \mu \mathrm{l}$ alınarak içerisinde NA besi ortamı bulunan petrilere yayma yöntemi ile ekim yapılmıştır, $25^{\circ} \mathrm{C}^{\prime}$ de 24 saat inkübasyona bırakılmıştır. İnkübasyon sonucunda Petri yüzeyinde farklı kolonilerden saflaştırılmalar yapılmıştır.

Aday antagonist bakteri izolatları ile denemeler yapılmadan önce tütün HR testi yapılarak negatif sonuç veren izolatlar aday antagonist olarak değerlendirilmiş, eğik olarak hazırlanmış YDCA besi ortamına ekimleri yapılarak biyolojik etkinlik çalışmalarında kullanılmak üzere $+4{ }^{\circ} \mathrm{C}^{\prime}$ deki buzdolabında muhafaza edilmiştir.

\section{Aday antagonist bakteri izolatların antagonistik etkinliğinin belirlenmesi}

İzolasyonlar sonucu zeytin yaprak ve toprağından elde edilen aday antagonist bakteri izolatlarının biyokontrol etkinlikleri in vitro koşullarda KB besi yerinde ikili karşılaştırma testi yapılarak belirlenmiştir. Antagonistik etkinliği belirlenecek aday izolatların 24 saatlik kültüründen KB besiyeri içeren petrilere $(9 \mathrm{~cm})$ birbirinden eşit uzaklıkta olacak şekilde 3 noktaya ekimleri yapılarak, $24 \pm 2^{\circ} \mathrm{C}^{\prime}$ de 48 saat inkübasyona bırakılmıştır. KB besi yerinde gelişen antagonist bakteri izolatları üzerine 24 saatlik patojen süspansiyonu $\left(10^{8}\right.$ hücre/ml) pülverize edilmiştir (Aysan ve ark., 2003; Bozkurt ve Soylu, 2019). Kontrol olarak antagonist bakteri yerine bitki patojeni $P$. syringae pv. syringae Naip-1 nolu izolat kullanılmıştır. İkili kültürlerin bulunduğu petriler $24 \pm 2^{\circ} \mathrm{C}^{\prime}$ de 48 saat inkübasyona bırakılmış ve 48 saat sonunda besiyerinde patojen gelişiminin engellenmesi sonucu oluşan engelleme zonları ile antagonist bakteri izolatlarının koloni çapları ölçülerek belirlenmiştir. Her bir bakteri izolatı için 3 petri kullanılmış ve deneme 3 kez tekrar edilmiştir.

\section{BULGULAR ve TARTIŞMA}

\section{Hastalıklı Bitki Örneklerinin Toplanması}

Tekirdağ ilinde zeytin üretimi yapılan önemli ilçe ve mahallelerde yer alan bahçelerdeki zeytin ağaçlarından toplanan 78 adet hastalıklı bitki örneklerinden yapılan izolasyon çalışmaları sonucunda toplam 52 adet patojen P. s. pv. savastanoi izolatı elde edilmiştir. Arazi çalışmaları sonucu 15 zeytin bahçesi gezilmiş ve bu bahçelerden 13 tanesinde hastalık tespit edilmiştir. Tekirdağ ilinde hastalığın yaygınlığı \%86.6 iken bulunma oranı \%4.11 olarak tespit edilmiştir (Çizelge 1.). 
Çizelge 1. Tekirdağ ilinde sörvey yapılan zeytin bahçeleri ve toplanan hastalıklı örnek sayısı Table 1. Olive orchards surveyed for disease in Tekirdag province and number of collected diseased sample

\begin{tabular}{cllccc}
\hline Bahçe & İlçe & Mevki & Alan (dekar) & Ăgaç sayısı & $\begin{array}{c}\text { Toplanan örnek } \\
\text { sayısı }\end{array}$ \\
\hline $\mathbf{1}$ & Şarköy & Mürefte Yolu & 3.5 & 130 & 6 \\
$\mathbf{2}$ & Şarköy & Kokarsu & 28.5 & 750 & 4 \\
$\mathbf{3}$ & Şarköy & Merkez & 4 & 150 & 10 \\
$\mathbf{4}$ & Mürefte & Mürefte & 7.5 & 200 & 8 \\
$\mathbf{5}$ & Mürefte & Mürefte & 3 & 100 & 6 \\
$\mathbf{6}$ & Mürefte & Mürefte yolu & 4.5 & 140 & 5 \\
$\mathbf{7}$ & Mürefte & Meselye & 1.5 & 50 & 5 \\
$\mathbf{8}$ & Mürefte & Meselye & 2 & 70 & 7 \\
$\mathbf{9}$ & Mürefte & Kalamış & 3 & 110 & 5 \\
$\mathbf{1 0}$ & Mürefte & Kalamış & 2 & 60 & - \\
$\mathbf{1 1}$ & Güzelköy & Güzelköy & 1 & 35 & - \\
$\mathbf{1 2}$ & Güzelköy & Güzelköy & 1 & 30 & 7 \\
$\mathbf{1 3}$ & Hoşköy & Ayazma & 1.5 & 50 & 6 \\
$\mathbf{1 4}$ & Hoşköy & Dere & 2 & 70 & 50 \\
$\mathbf{1 5}$ & Hoşköy & Su seddi & 1.5 & 50 & 7 \\
\hline
\end{tabular}

Tekirdağ ili zeytin üretimi yapılan Şarköy, Mürefte ve Hoşköy üretim alanlarında hastalı̆̆ın yaygınlığı \%100 olarak belirlenirken Güzelköy de ise hastalığa rastlanılmamıştır. Bu alanlarda hastalığın bulunma oranı Şarköy de \%1.94, Mürefte de \%6.34 ve Hoşköy de \%10.58 olarak hesaplanmıştır.

\section{Pseudomonas savastanoi pv. savastanoi izolasyonu ve tanılanması}

Şüpheli hastalık belirtisi gösteren bitkilerden izolasyonlar sonucu, King B besi ortamında zayıf floresan tipte, küçük yuvarlak ve kabarık olmayan tipte gelişen koloniler saflaştırılmıştır. Krem renkli floresan koloni gelişimleri gösteren izolatlar seçilerek morfolojik, biyokimyasal ve LOPAT testleri için kullanılmıştır (Lelliot ve Stead 1987).
Yapılan tanılama çalışmaları sonucunda elde edilen 52 izolatın Gram negatif özellikte olup, LOPAT testlerinde ---+ özellik göstererek Pseudomonas LOPAT 1b grubu içerisinde olduğu belirlenmiştir (Çizelge 2). LOPAT testinde kullanılan 52 izolatın tamamı tütün bitkisinde (Nicotiana tabacum) hipersensitif reaksiyon (HR) pozitif sonucunu vermiştir. Gerek morofolojik, gerek biyokimyasal ve LOPAT test sonuçlarına göre test edilen 52 izolatın tamamı P. S. pv. savastanoi olarak tanılanmıştır (Janse, 1992). İzolatların tamamı patojenite testi ve biyoetkinlik çalışmalarında kullanılmak üzere cam tüplerde eğik olarak hazırlanmış (YDCA) besi ortamına ekim yapılmıştır ve $+4{ }^{\circ} \mathrm{C}$ ' deki buzdolabında saklanmıştır.

Çizelge 2. P. s. pv. savastanoi izolatların tanı test sonuçları Tablo 2. Identification test results of P. s. pv. savastanoi isolates

\begin{tabular}{|c|c|c|c|c|c|c|c|c|}
\hline İzolat no & İzolat adı & İzole edildiği yer & Gram Reak. & $\mathrm{L}$ & 0 & $P$ & A & $T$ \\
\hline 1 & \$1 & Şarköy & - & - & - & - & - & + \\
\hline 2 & \$̧2 & Şarköy & - & - & - & - & - & + \\
\hline 3 & \$̧3 & Şarköy & - & - & - & - & - & + \\
\hline 4 & \$̧4 & Şarköy & - & - & - & - & - & + \\
\hline 5 & Ş5 & Şarköy & - & - & - & - & - & + \\
\hline 6 & \$̧6 & Şarköy & - & - & - & - & - & + \\
\hline 7 & Ş7 & Şarköy & - & - & - & - & - & + \\
\hline 8 & \$̧8 & Şarköy & - & - & - & - & - & + \\
\hline 9 & \$̧9 & Şarköy & - & - & - & - & - & + \\
\hline 10 & \$10 & Sarköy & - & - & - & - & - & + \\
\hline 11 & \$̧11 & Şarköy & - & - & - & - & - & + \\
\hline
\end{tabular}




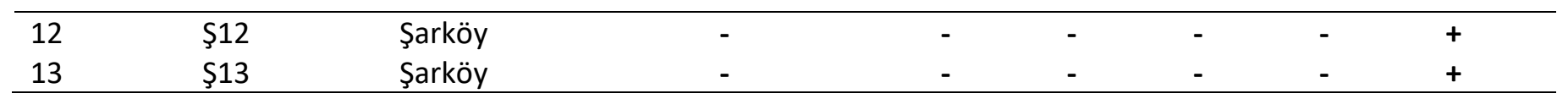

Çizelge 2. (Devamı) P. s. pv. savastanoi izolatların tanı test sonuçları

Tablo 2. (Continued) Identification test results of P. s. pv. savastanoi isolates

\begin{tabular}{|c|c|c|c|c|c|c|c|c|}
\hline 14 & Ş14 & Şarköy & - & - & - & - & - & + \\
\hline 15 & M15 & Mürefte & - & - & - & - & - & + \\
\hline 16 & M16 & Mürefte & - & - & - & - & - & + \\
\hline 17 & M17 & Mürefte & - & - & - & - & - & + \\
\hline 18 & M18 & Mürefte & - & - & - & - & - & + \\
\hline 19 & M19 & Mürefte & - & - & - & - & - & + \\
\hline 20 & \$̧20 & Şarköy & - & - & - & - & - & + \\
\hline 21 & \$̧21 & Şarköy & - & - & - & - & - & + \\
\hline 22 & \$̧22 & Şarköy & - & - & - & - & - & + \\
\hline 23 & \$̧23 & Şarköy & - & - & - & - & - & + \\
\hline 24 & \$̧24 & Şarköy & - & - & - & - & - & + \\
\hline 25 & \$̧25 & Şarköy & - & - & - & - & - & + \\
\hline 26 & \$̧26 & Şarköy & - & - & - & - & - & + \\
\hline 27 & \$̧27 & Şarköy & - & - & - & - & - & + \\
\hline 28 & \$̧28 & Şarköy & - & - & - & - & - & + \\
\hline 29 & \$̧29 & Şarköy & - & - & - & - & - & + \\
\hline 30 & \$̧30 & Şarköy & - & - & - & - & - & + \\
\hline 31 & \$̧31 & Şarköy & - & - & - & - & - & + \\
\hline 32 & \$̧32 & Şarköy & - & - & - & - & - & + \\
\hline 33 & Ş33 & Şarköy & - & - & - & - & - & + \\
\hline 34 & H34 & Hoşköy & - & - & - & - & - & + \\
\hline 35 & H35 & Hoşköy & - & - & - & - & - & + \\
\hline 36 & H36 & Hoşköy & - & - & - & - & - & + \\
\hline 37 & H37 & Hoşköy & - & - & - & - & - & + \\
\hline 38 & H38 & Hoşköy & - & - & - & - & - & + \\
\hline 39 & H39 & Hoşköy & - & - & - & - & - & + \\
\hline 40 & $\mathrm{H} 40$ & Hoşköy & - & - & - & - & - & + \\
\hline 41 & Ş41 & Şarköy & - & - & - & - & - & + \\
\hline 42 & \$̧42 & Şarköy & - & - & - & - & - & + \\
\hline 43 & Ş43 & Şarköy & - & - & - & - & - & + \\
\hline 44 & Ş44 & Şarköy & - & - & - & - & - & + \\
\hline 45 & \$̧45 & Şarköy & - & - & - & - & - & + \\
\hline 46 & \$̧46 & Şarköy & - & - & - & - & - & + \\
\hline 47 & \$̧47 & Şarköy & - & - & - & - & - & + \\
\hline 48 & \$̧48 & Şarköy & - & - & - & - & - & + \\
\hline 49 & \$̧49 & Şarköy & - & - & - & - & - & + \\
\hline 50 & Ş50 & Şarköy & - & - & - & - & - & + \\
\hline 51 & \$̧51 & Şarköy & - & - & - & - & - & + \\
\hline 52 & \$̧52 & Şarköy & - & - & - & - & - & + \\
\hline
\end{tabular}

L: levan tipte koloni oluşumu, O: oksidaz testi, P: pektolitik aktivite, A:arginin dehidrolaz, T: tütünde aşırı duyarlılık reaksiyonu

\section{Hastalık etmeni izolatların patojenisite testi}

P. s. pv. savastanoi olarak tanılanmış olan 52 izolatın King B besi ortamında geliştirilmiş 24 saatlik kültürleri zeytin fidanlarında yara açılarak inokule edilmek suretiyle patojenisite testleri yapılmıştır. İnokulasyondan yaklaşık
60 gün sonra yapılan değerlendirmelerde, yara dokusunun etrafında açık yeşil veya açık kahverengi, yumuşak ur belirtileri oluşturduğu görülmüştür. Ur belirtileri gösteren 52 izolatın patojenitesi pozitif olarak değerlendirilmiştir. Negatif kontrol olarak steril saf su 
inokule edilen bitkilerde herhangi bir ur belirtisine rastlanmamıştır. Urlu dokulardan yapılan reizolasyonlarda 52 adet re-izolat yeniden elde edilmiştir. İolasyonlarda, petrilerinin $25^{\circ} \mathrm{C}^{\prime}$ de 2 gün inkübasyonu takiben $+4{ }^{\circ} \mathrm{C}$ 'deki buzdolabında 24 saat bekletilmesi Mirik ve ark. (2008)'nın da belirttiği gibi izolasyon petrisindeki sarı renkli saprofit bakteri gelişimini baskılayarak yavaş gelişen patojenin gelişimine müsaade etmiştir. Böylelikle patojen bakteri re-izolatları kolaylıkla izole edilmiştir. Elde edilen re-izolatlarına yeniden tanı çalışmalarında kullanılan testler yapılmış ve hastalık etmenleri eğik besi yerinde $+4{ }^{\circ} \mathrm{C}$ ' de buzdolabında muhafaza edilmiştir.

Zeytin dal kanseri hastalığının ülkemizde yetiştirilen zeytin ağaçlarında varlığı uzun zamandır bilinmesine rağmen ilk çalışmalar Ege bölgesinde Azeri (1993) tarafından yapılan çalışmayla bildirilmiş olup, daha sonra yapılan rutin sörvey çalışmalarıyla, Aydın ve Muğla illerinde Tatı ve Benlioğlu (2004), Batı Akdeniz Bölgesinde Basım ve Ersoy (2000), Doğu Akdeniz Bölgesinde Adana, Hatay, Mersin, Osmaniye illerinde Mirik ve ark. (2004) ve Doksöz ve Bozkurt, (2020), Marmara Bölgesinde ise Mirik ve ark. (2007) tarafından hastalık etmeninin bulunuş oranı ve yaygınlıkları ortaya konulmuştur.

\section{Aday antagonist bakteri izolatların izolasyonu}

Sağlıklı zeytin ağacı ve topraktan NA besi ortamı bulunan petrilere yayma yöntemi ile yapılan izolasyonlar sonucu petri yüzeyinde gelişen farklı morfolojik yapıdaki kolonilerden aday antagonist bakteri izolatları elde edilmiştir. Saflaştırılmalar yapılmış antagonist bakteri izolatları ile biyoetkinlik testlerinden önce tütünde $\mathrm{HR}$ testi yapılarak negatif sonuç veren zeytin ağacından 50 , topraktan 60 adet olmak üzere toplam 110 adet bakteri izolatının $P$. s pv. savastanoi' ye karşı antagonistik etkinliklerinin belirlenmesi amacıyla ikili kültür denemelerinde kullanılmak için seçilmiştir

\section{Aday antagonistlerin hastalık etmenine karşı antagonistik etkinliklerinin belirlenmesi}

Sağ ıklı zeytin ağaçları ile topraktan izole edilen 110 aday antagonist bakteri izolatının antagonistik etkinliği in vitro koşullarda 3 nokta ekim deseni kullanılarak yapılan ikili kültür testleri ile belirlenmiştir. Bakteri kolonisi etrafında oluşan zon çapının bakteri koloni çapına bölünmesi suretiyle her izolat için etkinlik değerleri hesaplanmıştır. Her bakteri izolatı için ölçümler 3 farklı petri kabında yapılmış, deneme 2 farklı zamanda tekrar edilmiştir. İili kültür testleri sonucunda Çizelge 3' de görüldüğü gibi 110 aday antagonist izolatı arasında sadece 23 izolatın ikili kültür petrilerindeki besi yerlerinde hastalık etmenine karşı farklı çap büyüklüğünde engelleme (inhibisyon) zonları oluşturmuştur. Etkili olan 23 antagonist bakteri izolatın 9 tanesi zeytin ağacının çiçeklerinden, 3 tanesi yapraktan ve 11 tanesi ise zeytin ağacının yetiştirildiği kök bölgesi etrafındaki topraktan elde edilmiştir.

Çizelge 3. Aday antagonist bakteri izolatların ikili kültür testlerinde antagonistik potansiyellerinin belirlenmesi Tablo 3. Determination the antagonistic potentials of putative antagonist bacterial isolates in dual culture tests

\begin{tabular}{llllll}
\hline İzolat adı & Etkinlik değeri & İzolat adı & Etkinlik değeri & İzolat adı & Etkinlik değeri \\
\hline ES BAÇ 1 & 7.50 & ES BAY 8 & 22.00 & T68 & 22.00 \\
ES BAÇ 2 & 5.00 & ES BAY 9 & - & T69 & - \\
ES BAÇ 3 & - & ES BAY 10 & - & T70 & 3.5 \\
ES BAÇ 4 & - & ES BAY 11 & - & T71 & - \\
ES BAÇ 5 & - & ES BAY 12 & - & T72 & - \\
ES BAÇ 6 & - & ES BAY 13 & - & T73 & 10.00 \\
ES BAÇ 7 & 13.50 & ES BAY 14 & - & T74 & - \\
ES BAÇ 8 & 9.75 & ES BAY 15 & - & T75 & - \\
ES BAÇ 9 & - & ES BAY 16 & - & T76 & - \\
ES BAÇ 10 & 12.75 & ES BAY 17 & - & T77 & - \\
ES BAÇ 11 & - & ES BAY 18 & - & T78 & - \\
ES BAÇ 12 & 10.5 & ES BAY 19 & - & T79 & - \\
ES BAÇ 13 & - & ES BAY 20 & - & T80 & - \\
ES BAÇ 14 & - & T45 & - & T81 & - \\
ES BAÇ 15 & - & T46 & - & T82 & 19.25 \\
ES BAÇ 16 & - & T47 & - & T83 & - \\
ES BAÇ 17 & - & T48 & - & T84 \\
ES BAÇ 18 & - & T49 & - & T85 & - \\
\hline
\end{tabular}




\begin{tabular}{llllll}
\hline ES BAÇ 19 & - & T50 & - & T86 & - \\
ES BAÇ 20 & 13.50 & T51 & 9.25 & T87 & - \\
ES BAÇ 21 & - & T52 & - & T88 & - \\
\hline
\end{tabular}

Çizelge 3. (Devamı) Aday antagonist bakteri izolatların ikili kültür testlerinde antagonistik potansiyellerinin belirlenmesi Tablo 3. (Continued) Determination the antagonistic potentials of putative antagonist bacterial isolates in dual culture tests

\begin{tabular}{llllll}
\hline ES BAÇ 22 & 12.0 & T53 & - & T89 & - \\
ES BAÇ 23 & - & T54 & - & T90 & - \\
ES BAÇ 24 & - & T55 & - & T91 & 5.75 \\
ES BAÇ 25 & 9.75 & T56 & - & T92 & 20.00 \\
ES BAÇ 26 & - & T57 & - & T93 & - \\
ES BAÇ 27 & - & T58 & - & T94 & - \\
ES BAÇ 28 & - & T59 & 28.00 & T95 & - \\
ES BAÇ 29 & - & T60 & 9.25 & T96 & - \\
ES BAÇ 30 & - & T61 & - & T97 & - \\
ES BAY 1 & - & T62 & 9.25 & T98 & - \\
ES BAY 2 & 13.50 & T63 & - & T99 & 4.00 \\
ES BAY 3 & 10.10 & T64 & - & T100 & - \\
ES BAY 4 & - & T65 & - & T101 & - \\
ES BAY 5 & - & T66 & - & T102 & - \\
ES BAY 6 & - & T67 & - & T103 & - \\
ES BAY 7 & - & & & T104 & -
\end{tabular}

-: Antagonistik (engelleme) etkinliğinin olmadığını gösterir.

Hastalık ile kimyasal mücadelede yetersiz kalınmasından kimyasal mücadeleye alternatif olarak Oksel ve Mirik (2015)'in yaptığı üç farklı yöntemde, P. s. pv. savastanoi' nin farklı dozlarda bitki uçucu yağları kullanılarak patojen popülasyonuna olan antimikrobiyal etkisi araştırımıştır. Çalışmada 21 bitki uçucu yağı kullanılmış ve altı tane uçucu yağ (Bergamut Karabaş, Karanfil, Kekik, Okaliptus, Sarımsak) etkili sonuç vermesi bitki uçucu yağların etkili olduğunu göstermiştir. Aynı şekilde Bendaoud ve ark. (2009) okaliptüs (Eucalytus radiata)'tan elde ettikleri uçucu yağı zeytin dal kanseri etmeni $P$. s. pv. savastanoi' ye karşı etkinliklerini araştırdıkları çalışmalarında okaliptüsten elde edilen ekstraktların antibakteriyel etkilerinin bulunduğunu belirlemişlerdir. Bozkurt ve ark. (2020) tarafından yapılan çalışmada, Thymbra spicata var. spicata, Thymus serpyllum, Thymus sipyleus, Origanum syriacum, Origanum majorana, Ocimum basilicum, Mentha spicata, Melissa officinalis, Lavandula stoechas var. stoechas, Rosmarinus officinalis, Salvia officinalis, Laurus nobilis ve Foeniculum vulgare uçucu yağlarının kimyasal bileşenleri ve gal (ur) oluşturan bitki patojenik bakteriyel hastalık etmeni Rhizobium radiobacter, Pseudomonas savastanoi pv. savastanoi ve P.savastanoi pv. nerii'ye karşı antibakteriyel etkinlerini belirledikleri çalışmalarında uçucu yağların $P$. savastanoi pv. savastanoi (7.0-44.67 mm), ardından $R$. radiobacter (9.6-37.67 $\mathrm{mm}$ ) ve $P$. savastanoi $\mathrm{pv}$. nerii $(6.33-18.33$ $\mathrm{mm}$ ) ye karşı oldukça güçlü antibakteriyel etkinlik gösterdiğini, Lamiaceae familyasına ait bitkilerin uçucu yağlarının genellikle Lauraceae ve Apiaceae familyalarına göre daha etkili olduğu, test edilen tüm bakteri türlerine karşı en yüksek antibakteriyel aktiviteleri $O$. syriacum, $T$. serpyllum ve $T$. spicata var. spicata uçucu yağların gösterdiğini belirlenmiştir. Krid ve ark. (2011) zeytin alt suyu ve bundan elde edilen fenolik ekstraktların $P$. s. pv. savastanoi' ye karşı in vitro ve bitki üzerinde etkinliğini araştırmışlardır. In vitro koşullarda hastalık etmeninin gelişimini tamamen durdurduğunu saptamışlardır. Bitki denemelerinde kullandıkları 100,500 ve $1000 \mathrm{mg} \mathrm{L}^{-1}$ dozlarının sürgünlerde ur oluşumunu engellediğini belirtmişlerdir. Zadeh ve ark. (2008), farklı kültür bitkilerinden izole ettikleri patojen olmayan Pseudomonas izolatlarının patojen $P$. savastanoi' nin gelişimi üzerine olan etkisini araştırmışlardır. Çalışmada, antagonist izolatların ikili kültür petrilerinde $5-20 \mathrm{~mm}$ engelleme alanı oluşturarak patojen bakterinin gelişimini baskıladığını ortaya koymuşlardır. Mina ve ark. (2017), Frondihabitans sp. ve Paenibacillus sp. antagonist izolatlarının P. s. pv. savastanoi üzerine olan etkisini sera koşullarında gözlemlemişlerdir. Denemede 2 yaşındaki zeytin fidanlarına antagonist bakteri ve patojen $P$. s. pv. savastanoi uygulaması yapılmıştır. Uygulamadan 120 gün sonra yapılan değerlendirmede antagonist bakterilerin, $P$. s. pv. savastanoi populasyonu üzerinde 
etkili olduğu belirlenmiştir. Bozkurt ve Soylu (2019), elma ağaçlarının kök ve kök boğazı bölgelerinden 85 aday epifitik ve endofitik bakteri izolatın antagonist etkinliğini kök ur hastalık etmeni $R$. radiobacter'i baskılama yeteneğini in vitro ikili kültür ve in vivo testleri ile belirledikleri çalışma sonuçlarına göre Pseudomonas, Pantoea, Serratia and Bacillus cinslerine dahil farklı türlere ait 12 izolatın besi ortamı üzerinde patojene karşı ortalama 5.0-27.3 mm çapında arasında değişen engelleme zonları oluşturduğunu, Pseudomonas putida 1-4en izolatının diğer izolatlara kıyasla havuç dilimi üzerinde ur oluşumunu önemli düzeyde baskıladığını bildirmişlerdir.

Sonuç olarak, zeytin ağaçlarının P. s. pv. savastanoi ile enfekteli olması, dal ve sürgünlerde ender olarak da yaprak ve meyvelerde tümör ve gal oluşumu gibi aşırı büyüme ile sonuçlanmaktadır. P. s. pv. savastanoi zeytin dal kanseri hastalığı, dünya genelinde zeytin ağaçlarının en önemli hastalıklarından bir tanesidir. Hastalığın neden olduğu kayıplar büyük ölçüde coğrafik konum ve zeytin çeşitlerine bağlı olduğu için zararı tahmin etmek zor olsa da, enfekte olmuş ağaçlarda büyüme ve verim orta ve ağır derecede etkilenmekte, ayrıca meyvelerin büyüklügü̈ ve kalitesi azalmaktadır (Schroth ve ark., 1973; Young, 2004, Quesada ve ark., 2010). Hastalık etmeninin zeytin üretim alanlarında, Çanakkale de $\% 100$, Balıkesir de \%81, Tekirdağ da \%66, Bursa da \%4, Hatay ili Samandağ, İskenderun ve Arsuz ilçelerinde \%90 oranında yaygınlık gösterdiği belirlenmiştir (Mirik ve Aysan, 2011; Doksöz ve Bozkurt, 2020).

Hastalık etmeni ile mücadele, patojenin konukçu aralığının geniş olmasından dolayı oldukça zordur. Mevcut kontrol stratejileri arasında sürekli bakırlı pestisit kullanımının toksisite, dayanıklıık, çevre kirliliği, insan ve hayvan sağlığında tehlikeler gibi istenmeyen etkilere neden olması, alternatif olarak antagonist fungus ve bakteri kullanarak bitki patojenlerinin biyolojik kontrolü bitki hastalıklarının kontrolünde önemli bir yer almaktadır (Lavermicocca ve ark., 2002).

Çalışmamızda zeytin dal kanseri hastalık etmenine karşı antagonistik etkinliğin araştırıldığı, zeytin yaprak ve toprak örneklerinden elde edilen 110 adet izolat arasında engelleme etkinliği gösteren izolatlar ikili kültür denemeleri ile belirlenmiştir. Yapılan önceki çalışmalarda, Bacillus subtilis F1 ve F4 izolatlarının patojen $P$. S. pv. savastanoi üzerinde etkili olduğunu göstermiştir. Bacillus subtilis' in antimikrobiyal aktivite, metabolit üretimi ve sistemik direnç gibi mekanizmaları aktif hale getirilerek patojen $P$. S. pv. savastanoi' nin gelişimini baskıladığı belirlenmiştir (Shoda, 2000; Whipps, 2001). P. s. pv. savastanoi ile mücadele Bacillus ve Pseudomonas türlerinin yaygın olarak kullanımının yanı sıra, bazı Rhizobium türlerininde ürettikleri bakteriyosinler ile patojen gelişiminde etkili olduğu belirlenmiştir (Rokni Zadeh ve ark., 2008; Kacem ve ark., 2009)

Sonuç olarak bu çalışmada zeytin üretim alanlarında bakteriyel dal kanserine sebep olan $P$. $s . \quad$ pv. savastanoi'nin klasik testler ile tanısı; yaygınlığı ve zeytin üretim alanlarından hastalık belirtisi götermeyen zeytin yaprak çiçek ve toprak örneklerinden elde edilen izolatların antagonistik aktiviteleri ortaya konulmuştur. Tekirdağ ili Şarköy ilçesine bağıı Mürefte, Güzelköy ve Hoşköy yerleşkesi zeytin üretim alanlarında patojenin varlığı tanılanarak \%86.6 oranında yaygın olduğu belirlenmiştir. Aday antagonist bakteri izolatlarının patojen gelişimini baskılaması üzerine yapılan çalışmada, zeytin çiçeğinden elde edilen 9 , zeytin yaprağından 3 , topraktan elde edilen 11 olmak üzere toplam 23 tanesi 4.0-28.00 etki değeri arasında inhibisyon zonları oluşturarak patojenin gelişimini baskıladığı tespit edilmiştir. Bu gözlemler sonucu patojen bakterinin biyolojik mücadelesi ile umut var sonuçlar olabileceği ortaya konulmuştur.

\section{ÖZET}

Amaç: Zeytin (Olea europaea) ağaçlarında dal kanseri hastalığı bakteriyel hastalık etmeni Pseudomonas savastanoi pv. savastanoi tarafından neden olur. Hastalık etmeni zeytin dallarında hastalığa özgü tipik gal (ur) oluşumuna neden olur. Bu çalışmada 2016-2017 yılları arasında Tekirdağ ilinde zeytin bahçelerinde dal kanseri etmeni $P$. savastanoi pv. savastanoi' nin tanısı ve il genelinde yaygınlığı ile biyolojik mücadele olanaklarını araştırılması amaçlanmıştır.

Yöntem ve Bulgular: il genelinde yetişen zeytin çeşitlerinden 78 adet hastalıklı bitki örneği toplanmış ve 52 adet hastalık etmeni izolatı elde edilmiş ve tanılanmıştır. Elde edilen ve P. savastanoi pv. savastanoi olarak tanılanan tüm bakteri izolatları, patojenite testi yapılan zeytin fidanlarında ur oluşumuna neden olmuş ve King's $B$ besi ortamında zayıf floresan pigment üretmiştir. Tütün yapraklarında aşırı duyarlılık reaksiyonu oluşturan izolatların tamamı Gram, oksidaz, pektolitik aktivite, levan ve arginin dehidrolaz negatif olup, LOPAT 1b grubunda yer aldığı belirlenmiştir. Biyokimyasal ve morfolojik sonuçlara göre izolatların tamamı Pseudomonas savastanoi pv. savastanoi olarak tanılanmıştır. Yapılan çalışmalarla zeytin dal kanseri hastalığının Tekirdağ ilinde yaygınlığı \%86.6 oranında olduğu belirlenmiştir. Sağlıklı zeytin ağaçlarından ve yetiştiği topraktan elde edilen toplam 110 antagonist bakteri izolatları ile in vitro koşullarında yapılan ikili 
kültür denemeleri sonucunda, 23 antagonist izolatın besi yeri üzerinde hastalık etmenin gelişimini 3.5-28.00 etki değeri arasında inhibisyon zonları oluşturarak baskıladığı tespit edilmiştir.

Genel Yorum: Zeytin dal kanseri hastalığının Tekirdağ ili için dikkate alınması gereken bir hastalık olduğu ortaya çıkmıştır.

Çalışmanın Önemi ve Etkisi: Bu çalışma Tekirdağ ili zeytin alanlarında dal kanseri hastalığının mevcut durumunu ortaya koymuştur. Hastalığın güncel durumunun ortaya çıkarılması ve antagonist bakteri izolatlarının patojen gelişimini baskılaması üzerine yapılan çalışmalar hastalıkla mücadele amacı güden diğer çalışmalara için de önem taşımaktadır.

Anahtar Kelimeler: Zeytin dal kanseri, zeytin, LOPAT, tanı, biyokontrol.

\section{TEŞEKKÜR}

Bu çalışma NKÜBAP tarafından NKUBAP.03.YL.17.112 numaralı proje ile desteklenmiştir. Makale yazımında desteklerinden dolayı Araş.Gör.Dr. Cansu ÖKSEL'e teşekkür ederiz.

\section{ÇIKAR ÇATIŞMA BEYANI}

Yazar(lar) çalışma konusunda çıkar çatışmasının olmadığını beyan eder.

\section{ARAŞTIRMACILARIN KATKI ORANI BEYANI}

Yazarlar çalışmaya eşit oranda katkı sağlamış olduklarını beyan eder.

\section{KAYNAKLAR}

Anonim (2020) Tarım üretim piyasaları. https://arastirma.tarimorman.gov.tr (Erişim Tarihi: 15 Şubat 2021).

Azeri T (1993) Research on olive leaf spot, olive knot and Verticillium wilt of olive in Turkey. EPPO Bulletin, 23: 437-440.

Aysan Y, Şahin F, Mirik M, Dönmez MF, Tekman H (2003) First report of crown gall of apricot (Prunus armeniaca) caused by Agrobacterium tumefaciens in Turkey. Plant Pathology 52: 793.

Basim H, Ersoy A (2000) Batı Akdeniz Bölgesinde zeytin ağaçlarında Pseudomonas savastanoi pv. savastanoi tarafından oluşturulan bakteriyel dal kanseri hastalığının yayılışı ve hastalık etmeninin tanısı. Türkiye 1. Zeytincilik Sempozyumu 6-9 Haziran 2000, Bursa, sayfa: 310-315.

Bendaoud H, Bouajila J, Rhouma A, Savagnac A, Romdhane M (2009) GC/MS analysis and antimicrobial and antioxidant activities of essential oil of Eucalyptus radiata. Society of Chemical Industry 2.

Bozkurt IA, Soylu S, Mirik M, Ulubas Serce C, Baysal Ö (2014) Characterization of bacterial knot disease caused by Pseudomonas savastanoi pv. savastanoi on pomegranate (Punica granatum L.) trees: a new host of the pathogen. Letters In Applied Microbiology 59(5): 520-527.

Bozkurt IA, Soylu S (2019) Elma kök uru hastalığı etmeni Rhizobium radiobacter'e karşı epifit ve endofit bakteri izolatlarının antagonistik potansiyellerinin belirlenmesi. Tekirdağ Ziraat Fakültesi Dergisi 16: 348-361.

Bozkurt IA, Soylu S, Kara M, Soylu EM (2020) Chemical composition and antibacterial activity of essential oils isolated from medicinal plants against gall forming plant pathogenic bacterial disease agents. KSU Tarım ve Doğa Derg. 23: 1474-1482.

Conner KN, Zhang L, Jacobi J, Putnam M L (2013) First report of bacterial gall on Loropetalum chinense caused by Pseudomonas savastanoi in the United States. Disease Notes 97(6): 835.

Doksöz S, Bozkurt IA (2020) Hatay ili zeytin üretim alanlarında zeytin dal kanseri (Pseudomonas savastanoi pv. savastanoi) hastalığının belirlenmesi. Türk Tarım ve Doğa Bilimleri Dergisi 7: 96-103.

FAO (2019) Food and Agriculture Organization of The United Natıons Statistics Division. Web: Http://Bit.Ly/26dlhbl (Erişim Tarihi: 12 Şubat 2021).

Gemas VJV, Almadanim MC, Tenreiro R, Martins A, Fevereiro P (2004) Genetic diversity in the olive tree (Olea europaea L. subsp. europaea) cultivated in portugal revealed by RAPD and ISSR Markers. Genetic Resources and Crop Evolution 51(5): 501-511.

lacobellis NS, Caponero A, Evidente A (1998) Characterization of Pseudomonas syringae ssp. savastanoi Strains isolated from ash. Plant Pathology 47(1): 73-83.

Janse JD (1981) The bacterial disease of ash (Fraxinus Excelsior) caused by Pseudomonas syringae subsp. savastanoi pv. fraxini. II. Etiplogy And Taxanomic Considerations. Eur. J. For. Pathol. 11: 425-438.

Janse JD (1982) Pseudomonas syringae subsp. savastanoi (Ex Smith) subsp. Nov., Nom. Rev., The bacterium causing excrescences on Oleaceae and Nerium oleander L. International Journal of Systematic And Evolutionary Microbiology 32(2): 166-169.

Janse JD (2005) Phytobacteriology principles and practice. CABI, 359, USA 
Klement Z, Goodman RN (1967) The hypersensitive reaction to infection by bacterial plant pathogens. Ann. Rev. Phytopathol. 5: 17-44.

Klement Z, Rudolph K, Sand DC (1990) Methods in phytobacteriology. Akademia Kiado, Budapest, 568p.

Krid S, Bouaziz M, Triki MA, Gargouri A, Rhouma A (2011) Inhibition of olive knot disease by polyphenols extracted from olive mill wate water. Journal of Pathology 93(3): 561-568.

Lavermicocca $P$, Lonigro LS, Valerio F, Evidente A, Visconti A (2002) Reduction of olive knot disease by a bacteriocin from Pseudomonas syringae pv. ciccaronei. Applied and Environmental Microbiology 1403-1407.

Lelliott RA, Stead DE (1987) Methods for the diagnosis of bacterial diseases plants. Balackwell Scientific Publications, Oxford, UK. 26 pp.

Mina D, Santos A, Pereira J, Lino-Neto T, Baptista P (2017) Biological control of Pseudomonas savastanoi pv. savastanoi by two bacterial isolated from olive tree phyllosphere. $15^{\text {th }}$ Congress of the Mediterranean Phytopathological Union, Cordoba, Spain.

Mirik M, Aysan Y, Cinar O, Sahin F (2004) Türkiye'de çeşitli bitkilerden izole edilen Pseudomonas savastanoi izolatlarınınn fenotipik karakterizasyonu. Türkiye I. Bitki Koruma Kongresi, 139, Samsun.

Mirik M, Aysan Y (2006) Doğu Akdeniz Bölgesinde zakkum, yasemin, mersin ve cılbırtı çalılarında Pseudomonas savastanoi'nin neden olduğu bakteriyel ur hastalığı üzerine araştırmalar. III. Ulusal Süs Bitkileri Kongresi, 311-317, İzmir

Mirik M, Aysan Y, Büyükyılmaz M (2007) Türkiye'nin marmara bölgesi zeytin üretim alanlarında Pseudomonas savastanoi pv. savastanoi izolatlarının elde edilmesi ve yaygınlığı üzerine araştırmalar. II. Bitki Koruma Kongresi, Isparta

Mirik M, Aysan Y (2011) Marmara bölgesinde zeytin dal kanseri hastalığının yaygınlığı ve Pseudomonas savastanoi pv. savastanoi izolatlarının fenotipik ve genotipik karakterizasyonu. Tarım Bilimleri Dergisi 17(4).

Oksel C, Mirik M (2015) Zeytin dal kanseri etmeni Pseudomonas savastanoi pv. savastanoi' ye karşı in vitro koşullarda farklı uçucu yağların etkisi. Bitki Koruma Bülteni 55(4): 265-275.

Quesada CA, Lloyd J, Schwarz M, Patiño S, Baker TR, Czimczik Cl, Fyllas NM, Martinelli LA, Nardoto GB, Schmerler J (2010) Variations in chemical and physical properties of Amazon forest soils in relation to their genesis. Biogeosciences 7: 1515-1541.
Ramos C, Matas IM, Bardajı L, Aragon IM, Murillo J (2012) Pseudomonas savastanoi pv. savastanoi: some like it knot. Molecular Plant Pathology 13(9): 998-1009.

Rokni ZH, Khavazi K, Asgharzadeh AM, De Mot HR (2008) Biocontrol of Pseudomonas savastanoi pv. savastanoi, causative agent of olive knot disease: antagonistic potential of non-pathogenic rhizosphere isolates of fluorescent Pseudomonas. Commun. Agric. Appl. Biol. Sci. 73:199-203.

Schroth MN, Hildebrand DC (1968) A chemotherapeutic treatment for selectively eradicating crown gall and olive knot neoplasms. Phytopathology 58(6): 848.

Shoda M (2000) Bacterial control of plant disease. J. Biosci. Bioeng. 89: 515-521.

Smith EF (1908) Recent studies on the olive-tubercle organism. U.S. Dept. Agr. Bur. Plant Indust. Bull. No. 131 Part, IV.

Soylu S, Sülü MS, Bozkurt IA (2016) Bitki büyüme düzenleyici ve biyolojik mücadele etmeni olarak bakteriyel endofitler. Mustafa Kemal Üniversitesi Ziraat Fakültesi Dergisi 21: 103-111.

Teviotdale BL (1994) Diseases of olive, in olive production manual. (L Ferguson, GS Sibbett, GC Martin, Eds.) P. 107. University of California Publication No. 3353.

Whipps JM (2001) Microbial interactions and biocontrol in the rhizosphere. Journal of Experimental Botany 52: 487-511.

Wilson EE (1965) Pathological histogenesis in oleander tumors induced by Pseudomonas savastanoi. Phytopathology 55: 1244-1249.

Young JM, Dye DW, Bradbury JF, Panagopoulos CG, Robbs CF (1978) A proposed and classification for plant pathogenic bacteria. New Zealand Journal of Agricultural Research 21: 153-177.

Young, JM (2004). Olive knot and its pathogens. Australasian Plant Pathology 33(1): 33-39.

Zadeh HR, Khavazi K, Asgharzadeh M, Hosseini-Mazinani M, De Mot R (2008) Biocontrol of Pseudomonas savastanoi, causative agent of olive knot disease: antagonistic potential of non-pathogenic rhizosphere isolates of fluorescent Pseudomonas. Comm. Appl. Biol. Sci. 73(1): 199-203. 